\title{
Planning of Greenhouse Vegetable Enterprises through Game Theory Approach in Mersin Province
}

\author{
Osman Uysal ${ }^{1 *}$, Ufuk Gültekin ${ }^{2}$ \\ ${ }^{1}$ ALATA Horticultural Research Institute, Erdemli, Mersin \\ ${ }^{2}$ Department of Agricultural Economics, The University of Cukurova, Balcall, Adana
}

\begin{abstract}
The aim of this study was to plan the enterprises which apply greenhouse vegetable farming in Mersin province by Game Theory (GT) approach. The main material of this study consisted of survey data obtained from 163 greenhouse vegetable producers in Mersin Province and the data included 2013-2014 production periods.

The average land size was determined as $14.47 \mathrm{da}$. According to results, $22.70 \%$ and $77.30 \%$ of the producers were determined as risk takers and risk averse, respectively. As a result of the production plans which were applied according to Game Theory approach, the production pattern changed according to the current state. Also, gross profit increased in the ratios of $15.55 \%$ and $8.46 \%$ for the producers who take and avoid risks, respectively.
\end{abstract}

Key Words: Mersin Province, risk, farm planning, Game Theory, greenhouse vegetable production.

\section{INTRODUCTION}

Agriculture sector is under the effect of a great number of risk factors generating from production, marketing, financing, technological development, socio economic characteristics of the producers and government interferences. Agricultural enterprises should consider the risk factors in order to take the right decisions. The producers encounter with both yield fluctuations generating from climate, infections and pests and price fluctuations in input and crop prices. Besides, changes in technology and increase in capital use complicate the rational decision making of the enterprises. The enterprises should consider the risk factors in agricultural production in order to take right decisions in free market conditions (Ceyhan, 2003; Gündüz, 2007; Çetin and Esengün, 2012).

Under risk factor, agricultural crops can be supported by the government with highest prices or the producers can evaluate the production sources by tending to provide the highest income.

\footnotetext{
* Corresponding Author: uysalosman@ hotmail.com
}

These kinds of decisions can be taken by doing planning especially in the agriculture sector in which risk and uncertainty is intensive. The factors in agricultural production can be optimized according to technical and economic conditions by a forward planning study (Miran, 1990).

The uncertainties in the agriculture can be partially controlled by game theory approach which is one of the planning methods. The aim of this study is to determine the most profitable production pattern in greenhouse vegetable farms under risk conditions by game theory approach. For this purpose, gross profits of the crops, which are produced and have production potential in the research area, were determined. Agricultural production plans for the enterprises were obtained by linear programming (LP) and game theory models and they were compared. By this way, optimum plans with minimum risks were obtained.

Many studies were conducted in different areas such as the determination of defending strategies and price and marketing strategies on game theory subject. 
The studies in agricultural subjects were generally about agricultural policy and applications, decision making criteria and selling periods of the agricultural products.

Studies related with game theory approach were conducted on the subjects such as the examination of the market in terms of competitiveness and agricultural sustainability (Becker and Thiele, 1994; Satti, 1998; Müller, 1999; Holsteiner, 2003; Dae-Seob and Lynn, 2006), basin and water management (Başaran Uysal and Bölen, 2006; Herath, 2006; Raquel et al. 2007), execution of the production and trade scenarios of rice which is a significant crop in production and foreign trade (Langham, 1963; Ghosh et al. 2003; Lee and Kennedy, 2007), execution of the risk status of the crops and composing of the enterprise plans (Miran and Dizdaroğlu, 1994; Miran, 1995; Vuruş Akçaöz, 2001; Özkan and Vuruş Akçaöz, 2002; Şahin, 2008; Adeoye et al. 2012, Taalimoghaddam and Karbasi, 2012), determination of the optimum selling periods of the crops (Özer and Özçelik, 2010; Uysal et al. 2014). Any study was not carried out by game theory approach on greenhouse vegetable farming which is significant in production and export and requires far too much technical information and experience and this reveals the importance of the research.

\section{MATERIALS AND METHODS}

The main material of the study consisted of survey data obtained from the producers in Erdemli, Akdeniz and Tarsus districts of Mersin province in 2015. Simple random sampling method was used in order to determine the number of the surveys (Güneş and Arıkan 1988; Çiçek and Erkan 1996).

$$
n=\frac{N * \sigma^{2}}{(N-1) * D^{2}+\sigma^{2}}
$$

In the formula;

$\mathrm{n}$ : Sample size, N: Number of the enterprises in the population, $\sigma 2$ : Variance of the population, $\mathrm{D}^{2}:(\mathrm{d} / \mathrm{t})^{2}$, d: deviation from average (\%5), t: table value corresponding to 95\% confidence limit (1.96)

Total of 1437 enterprises are registered in Mersin Directorate of provincial food, agriculture and livestock greenhouse registration system. Accordingly, the number of the surveyed enterprises were determined as 163 with 5\% error margin and in $95 \%$ confidence interval.

Input usage, crop yields, gross production values, variable costs and gross profits of the greenhouse crops were calculated according to the planting areas of the crops.

The attitudes of the producers against risks were determined. Economic behavior method, direct benefit function approach, alternative market choices, private sequence approach and range methods were determined in some studies which were conducted in order to determine the risk choices. If the risk determination process in a field study is easy, it is understood that it can be reached to the best result (Karahan, 2002; Günden, 2005; Şahin, 2008).

In many studies, risk irrelevant producers were included to risk averse groups as risk irrelevant status is a special case of risk averse (Ceyhan et al. 1997; Karahan; 2002; Gündüz and Esengün, 2007; Şahin, 2008; Kuriyama et al. 2010; Goswami and Choudhury, 2014).

Gross production value of each year was calculated by multiplying the yields of 2015 year with annual average real prices. Gross profit was calculated by subtracting the variable costs of 2017 year from the gross production value of each year. The gross profits, obtained from the primary data in the research area, were evaluated from 2015 year. The variability generating from the market was included to the model.

Linear programming model was applied for risk taker enterprises and Wald criteria of 
game theory approach was used for risk averse enterprises when making the production plans according to the risk levels (Miran, 1995; Özkan and Vuruş Akçaöz, 2002; Şahin, 2008).

\section{RESULTS AND DISCUSSION}

Average family labor force of the enterprises was calculated as 433.04 Male Labor Force Unit (MLFU). On the basis of the districts, potential family labor forces were determined as 470.67, 410.35 and 377.85 MLFU in Erdemli, Akdeniz and Tarsus districts, respectively.

Intensive labor force is required in greenhouse vegetable farming but the surveyed enterprises used only $41.77 \%$ of family labor force and $58.23 \%$ of the family labor force remained inactive. This depended on the employment of the major part of the family population in nonagricultural labors. In the districts, it was observed that the family labor force ratios differed due to the differences between the greenhouse production area sizes and the production patterns.

Intensive temporal labor force is used in greenhouse vegetable farming as it is a seasonal or annual production activity. Average of 1089.69 MLFU was used in the enterprises. When the greenhouse vegetable farms were evaluated on the basis of districts, it was determined that total of 410.86 MLFU was used in Erdemli district, 1677.09 MLFU was used in Akdeniz district which has the biggest greenhouse area presence and 1532.47 MLFU was used in Tarsus district which is similar to Akdeniz district. It was also determined that $89.39 \%$ and $16.61 \%$ of total labor forces were supplied from waged labor force and family labor force, respectively. The ratios of family labor force and waged labor force was determined to be quite close one another in Erdemli district. In Akdeniz district, $90.45 \%$ and $9.55 \%$ of total labor forces were supplied from waged labor force and family labor force, respectively. Besides, it was also concluded that $88.12 \%$ and $11.88 \%$ of total labor forces were supplied from waged labor force and family labor force, respectively in Tarsus district.

Average size land was determined as 14.47 da in the enterprises. Besides, $80.30 \%$ and $3.48 \%$ of total enterprise land comprised of domain land and rental land, respectively. Sharecropping in greenhouse farming generally occur between close relatives and the ratio of sharecropping area size was determined as $16.22 \%$ (Table 1).

Table 1. Distribution of the Enterprise Land by Ownerships

\begin{tabular}{|c|c|c|c|c|c|}
\hline 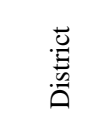 & 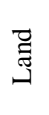 & 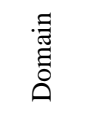 & $\frac{\widetilde{\pi}}{\mathbb{0}}$ & 总 & స్ㅠㅇ \\
\hline \multirow{2}{*}{ Erdemli } & $\mathrm{da}$ & 4.364 & 0.14 & 0.358 & 4.862 \\
\hline & $\%$ & 89.76 & 2.88 & 7.36 & 100.00 \\
\hline \multirow{2}{*}{ Akdeniz } & $\mathrm{da}$ & 18.642 & 0.843 & 3.334 & 22.819 \\
\hline & $\%$ & 81.69 & 3.70 & 14.61 & 100.00 \\
\hline \multirow{2}{*}{ Tarsus } & $\mathrm{da}$ & 12.027 & 0.542 & 6.494 & 19.064 \\
\hline & $\%$ & 63.09 & 2.84 & 34.07 & 100.00 \\
\hline \multirow{2}{*}{ Average } & $\mathrm{da}$ & 11.622 & 0.504 & 2.347 & 14.473 \\
\hline & $\%$ & 80.30 & 3.48 & 16.22 & 100.00 \\
\hline
\end{tabular}

Single-cropping pepper production was executed in $40.71 \%$ of the enterprises. Single cropping tomato production with the ratio of $10.74 \%$ and double cropping tomato production (autumn and spring) with the ratio of $10.39 \%$ followed this. In perennial crops, mandarin production had the highest ratio with $7.03 \%$. In the study, the ratios of orange, lemon and grape productions were determined as $4.11 \%, 3.26 \%$ and $2.07 \%$, respectively.

Average tractor number per enterprise was determined as 0.54. The highest tractor existence was determined in Tarsus district with the value of 0.67 and the minimum tractor existence was determined in Erdemli district with the value of 0.45 . The machine power per decare was determined to be high in Tarsus district with the value of $121.57 \mathrm{~h}$ and the machine power per decare was determined to be maximum in Erdemli district as the production areas were smaller according to other districts (Table 2). 
Table 2. Machine Existence in the Enterprises

\begin{tabular}{|l|r|r|r|}
\hline District & $\begin{array}{c}\text { Number } \\
\text { of tractors }\end{array}$ & \multicolumn{1}{|c|}{$\begin{array}{c}\text { Machine } \\
\text { power (h) }\end{array}$} & $\begin{array}{c}\text { Machine } \\
\text { power per } \\
\text { da (h/da) }\end{array}$ \\
\hline Erdemli & 0.45 & 34.05 & 7.00 \\
\hline Akdeniz & 0.59 & 111.08 & 5.09 \\
\hline Tarsus & 0.67 & 121.57 & 6.38 \\
\hline Average & 0.54 & 82.09 & 5.67 \\
\hline
\end{tabular}

The human labor usage in the enterprises differed according to the crops and the working time in greenhouse production was evaluated as $8 \mathrm{~h} /$ day. The highest human labor was used in single cropping tomato production with the value of 106.35 MLFU/da. in the enterprises. However, as double cropping vegetable production is intensively executed in the region, more human labor is required according to single cropping production. In this context, the highest human labor requirements were determined as 124.34 MLFU/da., 116.14 $\mathrm{MLFU} / \mathrm{da}$. and 113.22 MLFU/da. in tomato + bean, cucumber + bean and double cropping tomato production combinations, respectively. In perennial crops, the highest human labor requirement was determined in lemon production with the value of 20.38 MLFU/da., Mandarin, orange and grape productions followed this with the values of 19.78 MLFU/da., 18.12 MLFU/da., and 15.75 MLFU/da., respectively.

An intensive human labor is required in October-December months when the maintenance and harvesting processes of autumn crops are executed and March-June months when the maintenance and harvesting processes of spring crops are executed. Human labor supply is quite difficult in these periods in the research area. Alternative crop and crop combinations, which have production potential in the region, were included to the plan besides current production pattern in the planning study and the human labor was included to the plan with the current state. Additional capital was not used in order to reach to the optimum production plans. The restrictive used in the model were determined as production area (da), male labor force unit (MLFU), machine power (h) and capital (TL).

New crop and crop combinations were considered in the production patterns as alternative greenhouse crops, which have production potential in the region, were included to the planning models (Table 3).

\section{CONCLUSION}

The future of the agriculture and the solution of the problems depend on the efficient and healthy decisions on the basis of both producer and sector. For this reason, regarding the risk management in agriculture and planning with appropriate methods by the determination of risk and risk sources appear as a significant subject.

Intensive temporal labor force is used in greenhouse vegetable farming as it is a seasonal or annual production activity. Evaluation of potential family labor force in production may cause the decrease of the production costs.

The producers in the research area generally take the production decisions themselves. The effect of the women, who are active beginning from the maintenance till harvesting in greenhouse vegetable farming, is less than the men. Therefore, this must be considered in training and publishing activities which will be performed in the forthcoming periods.

Gross profit increase in the enterprises was provided by using different planning methods. Usage of linear programming was more advantageous in the ratio of $14.63 \%$ according to the current state. An advantage of $7.22 \%$ was obtained in game theory model in which the risk was lower.

The primary subject in planning studies is the determination of the technical coefficients used in production activities. 
Table 3. Planning Results of the Enterprises in Mersin Province

\begin{tabular}{|c|c|c|c|}
\hline \multirow{2}{*}{ Crops } & Current & LP & GT \\
\hline & $\mathrm{da}$ & da & da \\
\hline $\begin{array}{l}\text { Pepper (single } \\
\text { cropping) }\end{array}$ & 5.892 & 4.731 & 6.653 \\
\hline $\begin{array}{l}\text { Tomato (single } \\
\text { cropping) }\end{array}$ & 1.555 & - & 1.406 \\
\hline Tomato + tomato & 1.504 & - & 2.134 \\
\hline $\begin{array}{l}\text { Cucumber (single } \\
\text { cropping) }\end{array}$ & 0.604 & - & 0.242 \\
\hline $\begin{array}{l}\text { Green pepper } \\
\text { (single cropping) }\end{array}$ & 0.515 & 2.237 & 0.054 \\
\hline $\begin{array}{l}\text { Tomato }+ \\
\text { cucumber }\end{array}$ & 0.506 & - & - \\
\hline $\begin{array}{l}\text { Squash + green } \\
\text { pepper }\end{array}$ & 0.319 & - & - \\
\hline $\begin{array}{l}\text { Cucumber }+ \\
\text { green pepper }\end{array}$ & 0.239 & - & - \\
\hline Squash + pepper & 0.184 & - & - \\
\hline $\begin{array}{l}\text { Cucumber }+ \\
\text { tomato }\end{array}$ & 0.167 & 0.938 & - \\
\hline $\begin{array}{l}\text { Bean (single } \\
\text { cropping) }\end{array}$ & 0.123 & 1.562 & - \\
\hline $\begin{array}{l}\text { Eggplant (single } \\
\text { cropping) }\end{array}$ & 0.110 & - & 0.642 \\
\hline $\begin{array}{l}\text { Eggplant + } \\
\text { tomato }\end{array}$ & 0.104 & 0.276 & - \\
\hline $\begin{array}{l}\text { Cucumber }+ \\
\text { cucumber }\end{array}$ & 0.049 & - & - \\
\hline $\begin{array}{l}\text { Cucumber + } \\
\text { pepper }\end{array}$ & 0.037 & - & - \\
\hline $\begin{array}{l}\text { Eggplant + } \\
\text { pepper }\end{array}$ & 0.031 & - & - \\
\hline $\begin{array}{l}\text { Squash + } \\
\text { eggplant }\end{array}$ & 0.025 & - & 0.474 \\
\hline $\begin{array}{l}\text { Cucumber }+ \\
\text { melon }\end{array}$ & 0.025 & 0.556 & - \\
\hline $\begin{array}{l}\text { Cress }+ \text { green } \\
\text { pepper }\end{array}$ & 0.015 & - & - \\
\hline $\begin{array}{l}\text { Cauliflower }+ \\
\text { tomato }\end{array}$ & 0.012 & - & - \\
\hline Tomato + bean & 0.060 & - & - \\
\hline Lettuce + tomato & 0.006 & - & - \\
\hline $\begin{array}{l}\text { Lettuce + } \\
\text { cucumber }\end{array}$ & 0.006 & - & - \\
\hline Tomato + melon & - & 0.984 & - \\
\hline Cress + tomato & - & 0.804 & - \\
\hline Squash + tomato & - & - & 0.483 \\
\hline Lemon & 0.472 & 0.472 & 0.472 \\
\hline Grape & 0.300 & 0.300 & 0.300 \\
\hline Mandarin & 1.018 & 1.018 & 1.018 \\
\hline Orange & 0.595 & 0.595 & 0.595 \\
\hline Total & 14.473 & 14.473 & 14.473 \\
\hline
\end{tabular}

The changes in production techniques cause the variation of the inputs. In this context, the researchers should always follow the innovations in the research area. Price uncertainty, which occurs as a result of the production plan, is another subject. As the price formation in agricultural production activities occur within the scope of macro policies, they are directly associated with policy applications. For this reason, the planning studies including long term time series are important for presenting the probable effects of the policies.

\section{ACKNOWLEDGEMENTS}

I would like to express my thanks, especially to Ministry of Food, Agriculture and Livestock, Directorate General of Agricultural Research and Policy and Alata Horticultural Research Institute directors, researchers and other personnel for the valuable contributions and the support for this study.

\section{REFERENCES}

Adeoye, IB.., Yusuf, SA., Balogun, OS. and Alabuja, F. 2012. Application of game theory to horticultural crops in SouthWest Nigeria. ARPN J. of Agric. and Biol. Sci., 7(5):372-375.

Basaran Uysal, A. and Bölen, F. 2006. Planning in a Watershed and Game Theory. ITÜ Dergisi/a, Mimarlık, Planlama, Tasartm, 5-2 (2), 187-196. (in Turkish)

Becker, T. and Thiele, H. 1994. The Transformation of the Agricultural Sector. The Experience of East Germany, Annual Meeting of the American Agricultural Economics Association (AAEA), 7-10. San Diego, California

Ceyhan, V., Cinemre, H. A. and Demiryürek, K. 1997. Determination of Risk Behaviors in Terme District in Samsun Province. Ondokuz Mayis University, Faculty of Agriculture Research Series No: 3, 45 p., Samsun. (in Turkish)

Ceyhan, V. 2003. Risk Analysis in Agricultural Enterprises. Çorum 
Province Klzullrmak Basin Sample. Ondokuz Mayis University, Faculty of Agriculture Research Series No: 6, Samsun. (in Turkish)

Çetin, İ. and Esengün, K. 2012. Socioeconomic analysis of dry onion growing farms according to risk attitude in Amasya province. Gaziosmanpaşa University Journal of Agricultural Faculty, 2012, 29 (1), 81-92. (in Turkish)

Çiçek, A. and Erkan, O. (1996). Research and Sampling Methods in Agricultural Economics. Gaziosmanpaşa University, Agricultural Faculty Publications, No 12, Lecture Notes Series 6, Tokat. (in Turkish)

Dae-Seob, L. and Lynn, K. 2006. A political economic analysis of U.S. Rice Export Programs to Japan and South Korea: A Game-Theoretic Approach. American Journal of Agricultural Economics, 88(8):420-431.

Ghosh, D., Sharma, D.K. and Mattison, D.M. 2005. Goal Programming Formulation in Nutrient Management for Rice Production in West Bengal. International Journal of Production Economics, 95 (1), 1-7.

Goswami, K. and Choudhury, H. K. 2014. To Cultivate or Not? Examining Factors that Influence Jatropha Agriculture in North East India. SANDEE working papers, 82-14. Kathmandu: SANDEE.

Günden, C. 2005. A Study on Developing Flexible and Applicable Individual Production Plans for Region and Farm Size Level by Farmers via Fuzzy Goal Programming, The Case of Torbali, İzmir. (Unpublished doctoral dissertation). Ege University School of Natural and Applied Sciences, Department of Agricultural Economics, İzmir. (in Turkish)

Gündüz, O. and Esengün, K. (2007). Socioeconomic analysis of tomatoes farms according to risk attitude in the Central District of Tokat Province. Gaziosmanpaşa University Journal of Agricultural Faculty, 24(1), 51-62.
Gündüz, O. 2007. The Risks of Tomatoes Farms and Farm Planning Under Risk in Central District of Tokat Province. (Unpublished doctoral dissertation). Gaziosmanpaşa University, Graduate School of Natural and Applied Sciences, Tokat. (in Turkish)

Güneş, T. and Arıkan, R. (1988). Agricultural Economics Statistics. Ankara University, Agricultural Faculty Publications: 1049, Textbook: 305, Ankara. (in Turkish)

Herath, G. (2006). Game Theory Applications in Natural Resource Management: Review of Evidence, Problems and Potential. Meeting on Game Theory and Practice Dedicated to Development. 10-12 July, Natural Resources and the Environment, Instituto Agronomico Mediterraneo de Zaragoza, Spain.

Holsteiner, T. 2003. Ökonomisch Analyse zur Gestaltung von Naturschutzvertragen. Agrarpolirisches Seminar WS 2002/2003, Lehrstuhl Agrarpolitik, Institut für Agrarökonomie Christian Albrechtsuniversitat, Kiel.

Karahan, Ö. 2002. A Research on the Attitudes of Farmers towards Risks: Case of Aegean Region Farmers. (Unpublished doctoral dissertation). Ege University School of Natural and Applied Sciences, Department of Agricultural Economics, İzmir. (in Turkish)

Kuriyama, K., Hanemann W.M. and Hilger J.R. 2010. A Latent Segmentation Approach to a Kuhn-Tucker Model: An Application to Recreation Demand. Journal of Environmental Economics and Management, 60 (3): 209-220.

Langham, M.R. 1963. Game Theory Applied to a Policy Problem of Rice Farmers. American Journal of Agricultural Economics, 1963, vol. 45, issue 1, 151-162.

Lee, D.S. and Kennedy, P.L. 2007. A Political Economic Analysis of U.S. Rice Export Programs to Japan and South Korea: A Game Theoretic Approach. 
American Journal of Agricultural Economics, 89 (1): 104-115.

Miran, B. (1990). Advanced Methods to be used in the Planning of Agricultural Enterprises and Possibilities of use at Operation Level. Ege University Journal of Agricultural Faculty, 27(2): 228-244, İzmir. (in Turkish)

Miran, B. and Dizdaroğlu, T. 1994. Risk in Agricultural Farm Planning: An Approach to Game Theory, (in Turkish). The First Agricultural Economics Congress of Turkey, 8-9 September 1996, İzmir. (in Turkish)

Miran, B. 1995. Minimum price risky selling times for same selected storable crops in Ege Region. (in Turkish), Ege University Journal of Agricultural Faculty, 32(3):127-134. (in Turkish)

Müller, B. 1999. Price competition among dairies: a theoretical approach based on game theory. Kieler Milchwirtschaftliche Forschungsberichte, 51(2):165-190.

Özer, O.O. and Özçelik, A. 2010. Determination of the Best Marketing Time for Cotton by Game Theory. Journal of Agricultural Sciences, 16 (4):225-294. (in Turkish)

Özkan, B. and Vuruş Akçaöz, H. 2002. Game theory and its application to field crops in Antalya Province. Turk J. Agric., 26:303-309.

Raquel, S., Ferenc, S. and Emery, C.Jr., Abraham, R. 2007. Application of game theory for a groundwater conflict in Mexico. Journal of Environmental Management, 84(4):560-571.

Satti, M. 1998. International Trade in Dairy Products: Analysis Using Game Theory. Rivista di Politica Agraria, Rassegna Della Agricoltura, 16 (3):15-28.

Şahin, A. 2008. Farm Planning in Risk Conditions: Game Theory Approach. (Unpublished doctoral dissertation). Ege University School of Natural and Applied Sciences, Department of Agricultural Economics, İzmir. (in Turkish)

Taalimoghaddam, A. and Karbasi, A. 2012. Application of game theory to field crops in Khorasan-Razavi Province. Annals of
Biological Research, 2012, 3 (7):34613467.

Uysal, O., Subaşı, O.S. and Ünlü, M. 2014. Determination of the best marketing time for citrus. ALATARIM, 13(1): 27-36. (in Turkish)

Vuruş Akçaöz, H. 2001. Risk in Agricultural Production, Risk Analysis and Risk Attitudes: Applications for Cukurova Region. (Unpublished doctoral dissertation). Çukurova University, Graduate School of Natural and Applied Sciences, Department of Agricultural Economics, Adana. (in Turkish) 